\title{
THE ROLE OF HUMAN INSULIN GROWTH FACTOR (IGF) - AXIS IN CARCINOGENESIS
}

\author{
Wojciech KWAŚNIEWSKI ${ }^{1}$, Józef KOTARSKI ${ }^{2}$, Grzegorz POLAK ${ }^{1}$, \\ Anna GOŹDZICKA-JÓZEFIAK ${ }^{3}$, Jan KOTARSKI ${ }^{1}$ \\ ${ }^{1}$ Chair and Department of Oncological Gynaecology and Gynaecology, \\ ${ }^{2}$ Chair and Department of Obstetrics and Pathology of Pregnancy, \\ Medical University in Lublin \\ ${ }^{3}$ Department of Virology, Institute of Experimental Biology, \\ Adam Mickiewicz University in Poznań
}

DOI: $10.2478 / \mathrm{acb}-2014-0002$

Summary: The human insulin-like growth factor (IGF) system has attracted significant researcher interest due to its endocrine and autocrine / paracrine activities, mitogenic effects and the involvement in the regulation of proliferation, differentiation and apoptosis. The signaling pathways used by the IGF system impact cellular metabolism in a complex manner complex and many details are still unclear. Understanding the molecular mechanism of action of IGF's and their effects on cellular activity may provide a basis to develop new anticancer drugs. This review focuses on recent studies that expand our knowledge of the signaling pathways of IGF system.

Key words: IGFI, IGF-R, IGFBP, signaling pathways

\section{INTRODUCTION}

The IGF (Insulin-like Growth Factor) axis plays an important role in the control of growth, differentiation, proliferation and death processes. The IGF system consists of two ligands, IGF-1 and IGF-2 (Insulin-like Growth Factor I and II), two receptors, IGF-1R, IGF-2R (Insulin-like Growth Factor Receptor I and II), six IGF-binding proteins, IGF-IGFBP 1-6 (Insulin-like Growth Factor Binding Protein one to six) and specific IGFBP proteases. The same system encompasses also the Insulin-like Growth Factor Binding Protein-related Peptides (IGFBP-Pr), insulin and its receptors $[9,18,19,42,51]$. 
Alterations in an function of the IGF system lead to developmental abnormalities and to carcinogenesis, among other through the effect on apoptosis [33]. Recognition of IGF-1 cellular pathways, transmitting signals for cell death or survival, plays a key role in designing appropriate clinical treatment [33, 49, 86, 87, 91]. Modern antineoplastic therapies are based, among other, on silencing IGF-1 gene expression using the anti-sense technique (anti-sense oligonucleotide complementary to a fragment of IGF1 promoter), use of IGF-IR-specific monoclonal antibodies and inhibitors of IGF-I receptor [4, 57, 58, 59, 61]. IGF-IR-specific monoclonal antibodies are employed in phase I and II clinical trials [23, 31, 32, 67, 87]. IGF-IR-specific antibodies were demonstrated to inhibit development of mammary carcinoma [69], liver and colorectal cancer [78] and prostate cancer [61]. In neuroectodermal tumours IGF-IR-specific antibodies are responsible for some spectacular remissions and regressions of neoplastic disease [3].

IGF-1 and IGF-2, also termed somatomedins, belong to the group of peptides manifesting structural similarity to proinsulin. These small peptide hormones are members of the insulin family, which also includes relaxin. These proteins manifest $62 \%$ homology of amino acid sequence of IGF $1 / 2$. The structural similarity to insulin allows IGF-1 to bind to the insulin receptor and to exert insulin-like effects [84].

The insulin-like growth factor (IGF-1) is a 7647 Da peptide hormone, synthesized mainly in hepatocytes but also in ovary, fibroblasts, chondroblasts, osteoblasts, brain cells, epithelial cells in alimentary tract and in kidneys [84, 85]. Serum concentration of IGF-1 synthesized in liver (the so called hepatic IGF-1) depends on concentration of growth hormone $(\mathrm{GH})$ while synthesis of IGF-1 in peripheral tissues remains under control of not only GH but also of factors locally secreted by the surrounding cells and/or stroma [77, 87]. IGF-1 synthesized IGF-1 de novo in cells of various tissues exerts a mitogenic effect, stimulating synthesis of DNA, RNA and protein and in this way affecting cell proliferation, their differentiation and apoptosis [38, 39, 54, 87].

Principal regulators of IGF-1 synthesis, e.g. in genital system are estrogens and progesterone while expression of IGF-1 in bone cells is controlled, apart from GH, by parathyroid hormones and sex hormones $[62,71]$.

Plasma concentration of IGF-1 is low at birth $(20-60 \mathrm{ng} / \mathrm{ml})$, increases sevenfold during childhood and pubescence. In the second decade of life concentration of the protein decreases to $40 \%-50 \%$ of the concentration during pubescence and, then, decreasing further in parallel to decrease in secretion of GH [20,60]. A very important factor which determines serum IGF-1 concentration involves nutriture. The minimum feeding equalling energy input of $20 / \mathrm{kcal} / \mathrm{kg}$ per day and of protein equalling $0.6 \mathrm{~g}$ per day are indispensable for maintaining normal levels of IGF-I in plasma [18]. The function of circulating IGF-I seems to be well recognized but understanding of its local action has not been fully determined yet. 

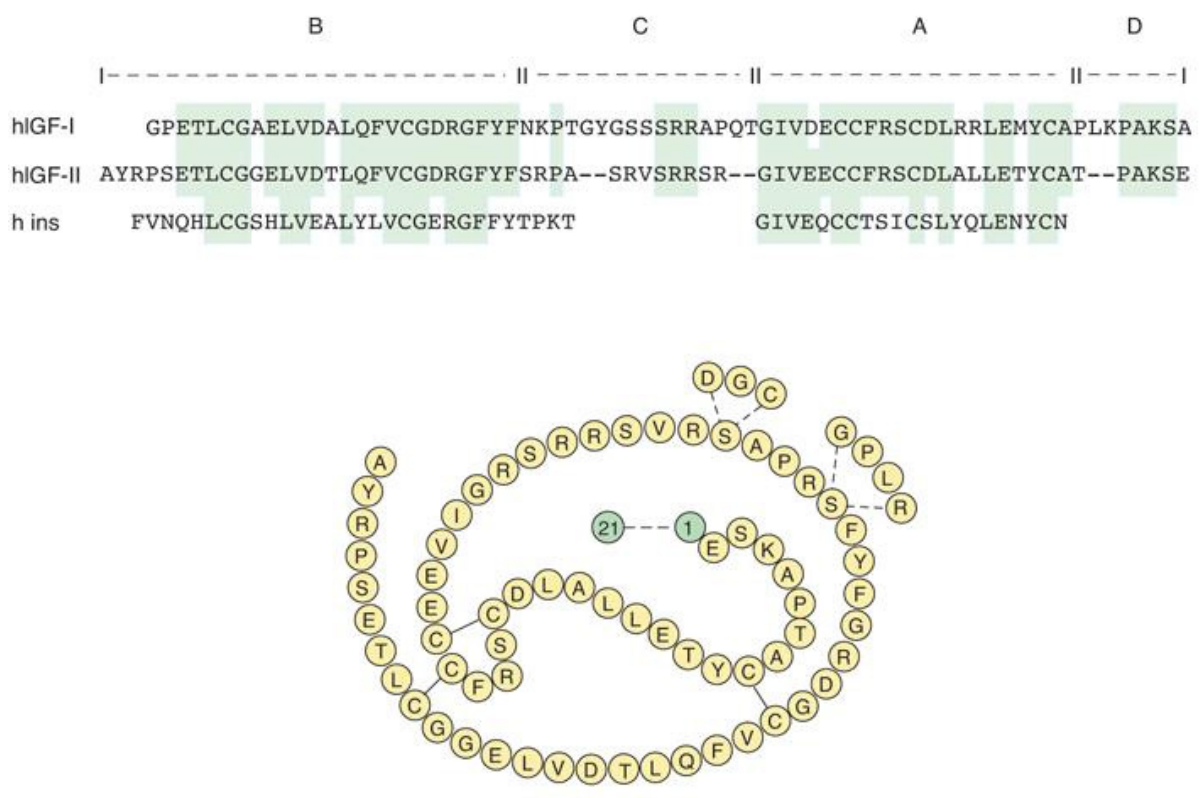

FIGURE 1. The structure of IGF-I, IGF-II and insulin on the basis of: KE Barrett, SM Barman, S Boitano, H Brooks, Ganong's of Medical Physiology, 23 rd ed. (Source: www.accesmedicine.com)

\section{STRUCTURE OF IGF-1 GENE AND ROLE IN CARCINOGENESIS}

The gene coding for human IGF-1 protein is located on the long arm of chromosome 12 (12q22-q24.1), it encompasses the region of around $90 \mathrm{kbp}$ and contains six exons separated by very long (1.9-50 kbp) introns [59]. Sequence of IGF-1 gene manifests a conservative character. Transcription of IGF-1 gene remains under control of two promoters, P1 and P2. It is estimated that around 90\% of IGF-1 transcripts originates from promoter P1. In human genome the promoter region of P1 encompasses 322 nucleotides located in 5'UTR of exon 1 and a regulatory region of 1630 nucleotides, manifesting an extensive polymorphism. The most conserved is the 5'UTR region of 322 nucleotides. The 1 promoter lacks sequences typical for promoters of other genes, such as TATA or CCAAT elements or regions rich in GC residues but it contains five fragments protected against digestion with DNAse: HS3A, HS3B, HS3C, HS3D, HS3E. The locus of HS3D is probably responsible for control of IGF-1 gene expression by estrogen [8]. In the regulatory region of $\mathrm{P} 1$ promoter, at the distance of around 960 nucleotides from the start site a microsatellite region is located, containing $19 \mathrm{CA}$ repetitions $[69,87]$. 
Promoter P1 of IGF-1 is located before exon 1 and P2 before exon 2 [87]. Depending on the site of transcription start, exons 1 and 2 code for two alternate signalling peptides, positioned at the amino end of IGF-1 molecule. The promoter regulatory regions contain binding elements for numerous transcription factors, including SP1 factor (Specifity Protein 1, SP-1) [81]. Exons 3 and 4 code for the mature IGF-1 protein while exons 4 and 5 undergo an alternative splicing of pre-mRNA yielding differentiated forms of IGF-1 gene transcripts in cells of individual tissues [53, 55, 69].

The complex post-transcriptional processing of primary pre-mRNA may produce 6 various mature transcripts (isoforms) of mRNA [7, 8]. Depending on the activated to transcription of a given molecule promoter P1 or P2 respectively transcripts of class I or II are distinguished. The alternative splicing yields mRNA isoforms of IGF1Ea, (containing exon 6 at $\mathrm{C}$ terminus), IGF1Eb (containing exon 5) and IGF1Ec (49 nucleotides of exon $5+$ exon 6 ). All the types of mRNA molecules provide templates for synthesis of IGF-1 protein. IGF-1 protein is synthesized in the form of propeptides which subsequently undergo proteolysis. As the result, N-terminal signal peptides coded by exons 1 and 2 are excised and the mature IGF-1 protein molecule is released, coded by exons 3 and 4 and C-terminal peptides E coded by exons 5 and/or $6[53,90]$. Differences in expression of individual isoforms are conditioned by several factors and depend, among other, on the type of tissue, cell age and its stage of differentiation. It is suggested that peptides E released during proteolysis of IGF-1 proprotein may fulfil different functions, independent of the mature form of IGF-1 protein [7, 81]. Role of the peptides was not yet fully recognised and it provides topic of many studies [93]. It is best recognised for the Ec peptide, termed MGF (Mechano Growth Factor, MGF) which participates in proliferation and differentiation of myoblasts [90 ].

Expression of IGF-1 gene is controlled by genetic factors (genetic polymorphism), IGFBP and their proteases, GH and its receptor, somatostatins, GHRH and their receptors. Concentration of IGF-1 in a cell is dependent, first of all, on GH and its receptor, with mediation of which activation of STAT (Signal Transducers and Activators of Transcription, STAT) takes place $[14,30]$. The phosphorylated STAT proteins undergo translocation to cell nucleus, in which in form of dimers they participate in activation of IGF-1 transcription and transcription of other cellular proteins [2].

The gene coding for IGF-2 contains 9 exons and it is located in the short arm of chromosome 11 (11p15.5), at a distance of 1.4 tbp from insulin gene. Its protein product consists of 67 amino acids. Transcription of IGF-2 gene takes place from four promoter loci (P1-4) situated respectively within exons 1, 4, 5 and 6 . In foetal life in liver promoters are active described as P 2-4 [15]. On the other hand, in the postnatal life transcription of IGF-2 remains mainly under control of promoter P1. Recently, IGF-2 was demonstrated to control growth of nervous cells in adults [14]. The gene of IGF-2 undergoes parental imprinting. In normal tissues the gene originating from mother is methylated and remains inactive while the paternal copy of the gene remains 
active [14]. Changes in methylation or loss of imprinting (LOI) may lead to development of neoplasia, e.g., Willms tumour, Beckwith-Widemann's syndrome, rhabdomysarcoma, Silver Russell's syndrome [88]. Initiation of IGF-2 transcription from various promoter loci and an alternative splicing are responsible for manifestation of several forms of IGF-2 gene transcript, similarly as it is in the case of IGF-1 [55].

\section{INSULIN-LIKE GROWTH FACTOR BINDING PROTEINS (IGFBP)}

In circulation IGF-1 is present in the free form and in the form complexed with proteins which bind IGF (IGFBP). Six IGF-binding proteins were identified, IGFBP of various affinity to IGF 1 and IGF 2 (tab. 1). Around $85-95 \%$ of total IGF-1 in serum forms a complex, consisting of IGF-1, IGFBP-3 and the acid-labile subunit (ALS) of $150 \mathrm{kDa}$ in molecular weight. Formation of the IGF: ALS complexes takes place in liver sinusoids. In such a complex half-life of IGF-1 is extended to 12-18 hours while for the free IGF-1 it is just few minutes [12]. Extending IGF-1 half-life, the complex protects the host against hypoglycaemia effects, induced by unbound insulin-like growth factors, influence bioavailability of free IGF in serum and inhibits transport of circulating IGF to target tissues $[13,22]$. The protein of IGFBP-3 fulfils an IGF-1 storing function and it restricts its access to receptors on cells in specific tissues $[18,73]$.

IGFBP proteins contain 16 to 20 cystein residues, manifesting high similarity of amino acid sequence on both ends of the molecule. The central region in IGFBP molecules manifests a very restricted similarity of amino acid sequence as well as it varies in the degree and type of post-translation modification by proteolysis, glycosylation and phosphorylation. The $\mathrm{N}$ terminus of the proteins, just after the signal peptide, contains 80-93 amino acid residues manifesting 58\% similarity. The domain contains 10 to 12 cystein residues. The content of cystein residues points to the potential for formation of a few ( 5 to 6 ) disulphide bridges. The $\mathrm{N}$ terminus of all IGFBP proteins, except of IGFBP-6, contains a highly conserved GCGCCxxC motif. In IGFBP proteins their $\mathrm{C}$ terminus also contains a conserved motif, the similarity of which approximates $34 \%$. In the $\mathrm{C}$ terminus 6 cystein residues are present.

Location of 5 cystein residues of a specific amino acid sequence manifests $37 \%$ similarity to the thyreoglobulin type I domain. The domain consists of 65 amino acid residues and it is tenfold repeated at the $\mathrm{N}$ terminus of thyreoglobulin molecule. The role of the thyreoglobulin domain in IGF 1 molecule remains unknown. It is suggested that it may be engaged in binding of IGF and in binding with the cell surface and extracellular matrix [51]. C terminus of IGFBP-1 and -2 molecules contains the RGD amino acid motif providing binding sites for integrins [83], 
while the proteins of IGFBP-3, -5 and -6 contain the heparin-binding motif (of xB$\mathrm{BBxxBx}$, where $\mathrm{B}$ stands for Arg, Lys or His, while $\mathrm{x}$ represents every other amino acid residue) engaged in binding of the cell to the surface and extracellular matrix [34]. Domains at the N and C ends of IGFBP molecules form third order structures manifesting high affinity in binding of IGF [43].

The central region in IGFBP molecule contains 55 to 95 amino acids manifesting around $15 \%$ similarity. In IGFBP-3 and -4 proteins amino acid residues are $\mathrm{N}$-glycosylated, in IGFBP-5 and -6 they are O-glycosylated. IGFBP-1, -3 and -5 proteins are also post-translationally modified by phosphorylation [80, 88]. The phosphorylated IGFBP-1 protein manifests a fivefold increased IGF-binding affinity. In turn, phosphorylation of IGFBP-3 protein increases strength of the protein interaction with ALS subunit and with cell surface [11].

IGF binding proteins contain also unique elements, responsible for differences in their physiological function. IGFBP-3 manifests the highest concentration in the post-natal blood and is synthesized mainly in Kupffer cells [1]. IGFBP-4 and IGFBP-6 probably inhibit physiological functions of IGF $[24,44]$. The protein is present in many extracellular body fluids [26]. IGFBP-1, $-2,-3,-4$ and -5 are frequently associated with components located at the surface of cell membrane or extracellular matrix $[44,82]$. Binding of IGFBP-5 to extracellular matrix (ECM) reduces eightfold its affinity to IGF-1. IGFBP-1,-2, $-3,-4$ and -5 manifest a comparable ability to bind IGF- 1 and IGF-2, while IGFBP-6 exhibits 100 -fold higher affinity to IGF-2 than to IGF-1 $[44,70]$

IGFBP act not only as carriers of IGF in circulation, they also control bioavailability of IGF-1 for the receptor in target tissues, modulate its functions and extend its half-life. In addition the IGF-binding proteins fulfil functions independent of the factors. It was demonstrated that IGFBP-1, -2, -3, -5 may be present in cell nucleus $[1,2,50,52]$. Specific IGFBP proteases exert a significant effect on activity of IGFBP and cell proliferation. For example, IGFBP-3 is a substrate for catepsin D and PSA. Degradation of IGFBP by proteases reduces affinity of the proteins for IGF 1 , and augments its bioavailability for IGF-1R receptor $[3,41]$. An increase in activity of proteases promotes development of tumours $[36,46,90]$.

Human genes coding for IGFBP manifest high similarity of their nucleotide sequences even if they markedly differ in size, ranging from $5.7 \mathrm{kbp}$ to $33 \mathrm{kbp}$. Except of IGFBP-3 gene, which contains 5 exons, including one undergoing no translation, all the remaining IGFBP genes contain four exons [87].

Affinity to IGF and capacity of binding it are manifested also by IGFBP-related protein, IGFBP-Pr (tab. 1). The proteins are included to the family of IGFBP due to their structural similarity and their ability to bind IGF. The domain located at $\mathrm{N}$ terminus of IBGFBP-Pr manifest high similarity to the N-terminal domain of IGFBP. The protein family includes, i.a., proteins such as Mac25 (follistatin (FS)-like protein), PSF (Prostacyclin-Stimulating Factor), TAF (Tumour Adhesion Factor), CTGF 
(Connective Tissue Growth Factor) [33]. Their role in the IGF system remains to be recognised. IGFBP-Pr are capable of binding IGF through the conserved region at the $\mathrm{N}$ terminus of the molecule with an affinity around 100-fold lower than IGFBP.

TABLE 1. Characteristics of IGF binding protein IGFBP

\begin{tabular}{l|c|c|c|c}
\hline Protein & $\begin{array}{c}\text { Molecular } \\
\text { weight }\end{array}$ & $\begin{array}{c}\text { Number of } \\
\text { amino acids }\end{array}$ & $\begin{array}{c}\text { Number of cyste- } \\
\text { in residues per } \\
\text { protein molecule }\end{array}$ & $\begin{array}{c}\text { Chromosomal } \\
\text { locus }\end{array}$ \\
\hline \multicolumn{5}{|c}{ IGFBP with high affinity to IGF } \\
\hline IGFBP-1 & 25.3 & 234 & 18 & $7 \mathrm{p}$ \\
\hline IGFBP-2 & 31.4 & 289 & 18 & $2 \mathrm{q}$ \\
\hline IGFBP-3 & 28.7 & 264 & 18 & $7 \mathrm{p}$ \\
\hline IGFBP-4 & 26.0 & 237 & 20 & $17 \mathrm{q}$ \\
\hline IGFBP-5 & 28.6 & 252 & 18 & $2 \mathrm{q}$ \\
\hline IGFBP-6 & 22.8 & 216 & 16 & 12 \\
\hline
\end{tabular}

IGFBP-related proteins (IGFBP-Pr) with low affinity to IGF

\begin{tabular}{c|c|c|c|c}
\hline $\begin{array}{c}\text { IGFBP-P(MAC25/TAF/ } \\
\text { PSF) }\end{array}$ & 26.4 & 256 & 18 & $4 \mathrm{q}$ \\
\hline $\begin{array}{c}\text { IGFBP-Pr2 } \\
\text { CTGF }\end{array}$ & 35.5 & 323 & 38 & $6 \mathrm{q}$ \\
\hline $\begin{array}{c}\text { IGFBP-Pr3 } \\
\text { NovH }\end{array}$ & 36.0 & 329 & 38 & $8 \mathrm{q}$ \\
\hline $\begin{array}{c}\text { IGFBP-Pr4 } \\
\text { Cyr61 }\end{array}$ & 39.5 & 358 & 38 & $1 \mathrm{p}$ \\
\hline $\begin{array}{c}\text { IGFBP-Pr5 } \\
\text { RCOP1/WISP-2/CTGF-L }\end{array}$ & 49.0 & 458 & 16 & \\
\hline $\begin{array}{c}\text { IGFBP-Pr6 } \\
\text { L56/HtrA }\end{array}$ & 18.1 & 165 & 18 & $20 \mathrm{q}$ \\
\hline $\begin{array}{c}\text { IGFBP-Pr7 } \\
\text { ESM-1 }\end{array}$ & 24.4 & 228 & 28 & \\
\hline
\end{tabular}

\section{RECEPTORS FOR INSULIN-LIKE GROWTH FACTOR 1R (IGF-1R) AND SIGNAL TRANSMISSION}

IGF act on cells through their specific receptors $[33,67,86]$. The receptor of IGF-1R for IGF-1 represents an important component of GH/IGF axis [63]. The protein represents a tetramer consisting of two identical extracellular subunits $\alpha$ and two identical transmembrane subunits $\beta$ linked to each other by disulphide bridges. The receptor of IGF-1R manifests high affinity to both IGF-1 and IGF-2. The ligands are bound to the cystein-rich domain in the receptor alpha subunit, which 
results in signal transmission through the transmembrane domain to the intracellular kinase domain in the beta subunit [9]. This leads to conformational alterations in beta subunit, autophosphorylation of tyrosine residues in positions 1149, 1150 and 1151 and to stimulation of tyrosine kinase (TK) receptor activity, which phosphorylates the receptor-linked substrate proteins. The domain contains ATP-binding sequences. For activation of TK receptor lysine in position 1003 of the protein is indispensable [9]. The IGF-1R receptor manifests the most pronounced affinity to IGF-1, followed by IGF-2 and insulin [74].

IGF-1R is manifested in cells of many tissue types. The number of receptors ranges from 20 to 35.000 per cell and their expression is strictly controlled by $\mathrm{GH}$ and and thyroxine [19]. The number of IGF-1R molecules increases under effect of other growth factors, such as Plateled-Derived Growth Factor (PDGF), Fibroblast Growth Factor (FGF), transforming growth factor- $\beta$ (TGF- $\beta$ ), Vascular Endothelial Growth Factor (VEGF) [72, 87].

IGF-1R, together with insulin receptor (IR), with which it shares $70 \%$ of amino acid sequence, belong to the family of tyrosine kinase type II receptors. Expression of IGF-1R is inhibited by Wilms ' tumour suppressor protein (WT1) and p53. IR consists of two extracellular subunits alpha and two transmembrane subunit beta with activity of tyrosine kinase [17]. Insulin receptors are much less numerous in the cells than IGF receptors as well as hybrid forms of the two receptors are known, including alpha IR, beta IR, alpha IGFR, beta IGFR [12]. The hybrid receptor is activated by insulin and, with higher affinity, by IGF-1. IR is present in two isoforms produced as a result of alternate splicing of exon 11: i/IRA, with absence of exon 11 and ii/IRB, containing exon 11. Insulin binds to both forms of the receptor [12, 28, 74].

Type II of IGF receptora (IGF-2R) is a monomer and significantly differs from the receptor for insulin and IGF-1R. The receptor manifests no tyrosine kinase activity and is less significant for stimulation of cell growth. It manifests affinity to IGF-2 and it binds ligands containing mannose- 6 phosphate. In a cell IGF-2R undergoes rapid endocytosis [6]. The receptor manifests properties of neoplastic transformation suppressor. Therefore, its absence in a cell leads to increase in free IGF-2, which activate IGF-1R and can stimulate cell proliferation [91].

Activation of IGF-1R occurs due to binding by the receptor of IGF-1 or IGF-2, which results in conformational changes in the receptor and in autoactivation of the receptor tyrosine kinase (fig. 2). The alterations initiate signal transfer in the cell, which leads to cell proliferation and inhibition of apoptosis. Activation of phosphatidylinositol 3' -kinase (PI3K) and of protein kinase-B (Akt/PKB) with mediation of IGF-1R involves the principal signalling pathway which protects cell from apoptosis. IGF-1R activates also other signal transmission pathways in the cell, responsible for control of cells proliferation and differentiation. One of the pathways leads to activation of mitogen-activated protein kinases (MAPK) [5]. Another pathway causes transplacement of calcium and activation of calcium-dependent cellular pathways [33]. 


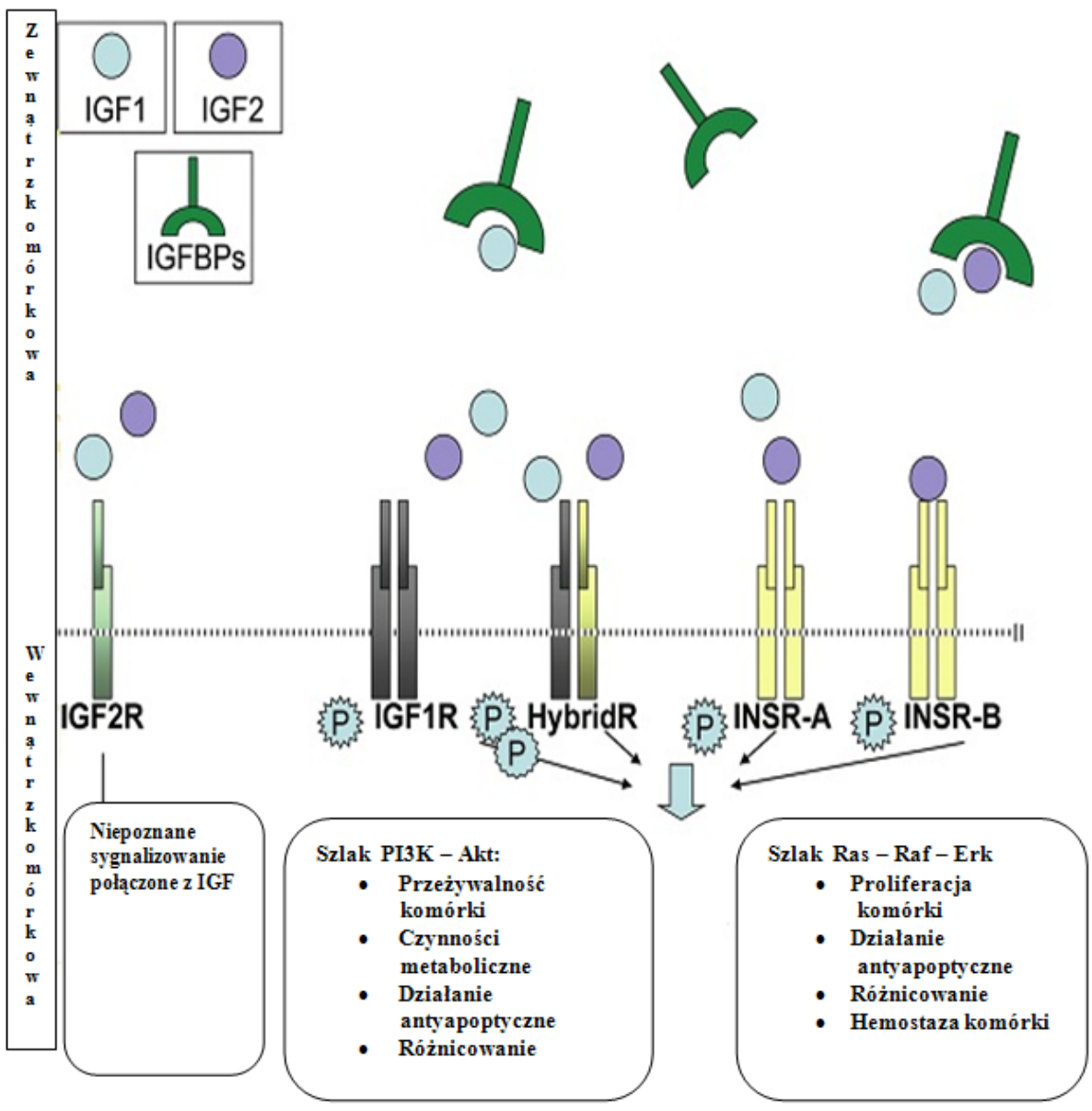

FIGURE 2. The members of the IGF axis and their signaling pathways. The signaling pathways activated by the IGF axis include the Ras-Raf-Erk signaling pathway and the phosphatidylinositol3-kinase/Akt (PI3K/Akt) signaling pathway. These pathways in turn activate a variety of different downstream signals (description below) [33]

Phosphorylation of the receptor and an increased inner activity of IGF-1R tyrosine kinase, linked to autophosphorylation of other receptor sites, result in phosphorylation of receptor-associated substrate proteins. Activated IGF-1R phosphorylates insulin receptor substrates -1 and -2 (IRS-1, -2), which bind to receptor tyrosine in position 950. The phosphorylated IRS interact with SH2 (Src Homoolgy-2) domains of phosphatidylinositol-3 kinase (PI3K), inducing its activation [45]. As the result, a stimulated glucose transport in the cell, an augmented contractility of cardiomyocytes and inhibition of apoptosis were noted, due to activation of numerous proteins and other molecules taking part in the processes [17]. Moreover, activation of 
PI3K catalyses phosphorylation of phosphatidylinositol 4,5-disphosphate (PIP2) to phosphatidylinositol 3,4,5-trisphosphate (PIP3). The reaction of PIP3 dephosphorylation develops with involvement of PTEN (Phosphatase and Tensin homolog deleted from chromosome-10) phosphatase. The phosphatase silences in the cell signals originating from receptor kinases, including those of IGF1-R [29, 47].

The activated PIP3 binds to PH (Homologue of Pleckstrin) domain of at least two AKT (v-akt murine thymoma viral oncogene) proteins and of Phosphoinositide -Dependent Kinase-1 (PDK-1). With participation of PDK-1, phosphorylation takes place of AKT protein treonine residue in position 308 and of protein kinase $\mathrm{C}$ proteins: PKC- $\lambda$ and PKC- $\xi(47,48)$. PKC in line with AKT are responsible for an increased rate of glucose uptake by the cell, facilitating translocation of glucose transporter-4 (GLUT4) from an endocytic vesicle to cell membrane [13]. Active AKT phosphorylates numerous proteins engaged in the apoptotic process and in this way inhibits their activities. The principal target of AKT involves BAD (BCL2 Antagonist of Cell Death) protein [21]. The unphosphorylated BAD is located in mitochondrial membrane, in which it interacts with BCL2 (B-Cell CLL/Lympho$m a-2)$ protein, blocking its anti-apoptotic activity. The phosphorylated BAD binds to a cytosolic protein 14-3-3 and is unable to interact with BCL2. AKT may also prevent initiation of caspases cascade by phosphorylation and inactivation of caspase 9. Moreover, ACT phosphorylates numerous pro-apoptotic proteins, belonging to the family of transcription factors, including FKHR (Forkhead transcriptional factor) and FKHRL1(Forkhead-Related family of mammalian transcription factor-1), inhibiting their activities. Activation of AKT leads also to a decreased expression of FASL (ligand of Fas) and of Fas-dependent apoptosis. Apart from inhibition of proapoptotic activities manifested by transcription factors, active AKT augments also levels of BCL2 and BCL-X antiapoptotic proteins and of numerous adhesion molecules of extracellular matrix. An increased activity of AKT leads also to expression of the antiapoptotic transcription factor, NF- $\kappa \mathrm{B}$ due to control of activity manifested by kinases of I-א B, IKKs (I-Kappa B Kinase). This results in degra-

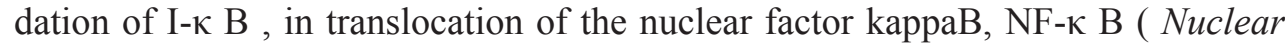
Factor-kappa B) to the cell nucleus and to activation of transcription manifested by anti-apoptotic genes. Further AKT-activated pathway is responsible for inhibition of activity manifested by glycogen synthase kinase-3 (GSK3), due to phosphorylation of serine residue in position 21 at the $\mathrm{N}$ terminus of subunit alpha and serine 9 in subunit beta of the protein [93]. The inhibited activity of GSK3 in response to IGF, results in dephosphorylation and activation of glycogen synthase and in stimulation of glycogen synthesis [51]

GSK3 catalyses also phosphorylation and inhibits activity of the factor which initiates synthesis of eukaryotic proteins (eukaryotic Initiation Factor-2B). Therefore, IGF-1R, by inhibition of GSK3 activity allows for dephosphorylation and activation of eIF2B, which leads to an increased protein synthesis. The unphosphorylated 
eIF4E (eukaryotic Initiation Factor-4E) is present in the cell in complexes with one of three proteins, 4EBP1, 4EBP2 or 4EBP3 (Eukaryotic initiation Factor-4E Binding protein). Phosphorylation of 4EBP induces decomposition of the eIFE-4EBP complex, release of eIE4E, which takes part in initiation of protein translation [87].

Substrates for phosphorylation with involvement of AKT kinase include also mTOR proteins. mTOR (mammalian Target Of Rapamycin) kinase integrates numerous cellular pathways, including IGF1 and 2. mTOR represents one of the main mediators in transmission of a mitogenic signal in the cell with involvement of IGF 1/PI3'K/AKT.[60, 87]

Activity of mTOR kinase resulted in activation of ribosomal proteins, p70S6K and S6, and in an increased protein synthesis [35]. mTOR kinase, S6K1, activated with mediation of IGF1 was shown to increase transcription of genes controlled through estrogen receptor (ER) alpha $[10,76]$. In breast cancer cells ER alpha together with BRCA1 protein binds to the controlling region of IGF1 gene inhibiting its transcription $[40,76]$. Defective BRCA1 protein activates the IGF1/Pi3'K AKT signal transmission pathway and accentuates a mitogenic signal $[40,75,79]$.

Also as a result of IGF-1R autophosphorylation activated SHC proteins (proteins containing SH2) are bound to the adaptor protein, GBR2 (the growth factor receptor bound protein-2), which initiates the SOS pathway in the IRS-independent manner. Subsequently, the complex activates the signal transmission pathway with participation of p21 RAS and initiates the phosphorylation cascade of RAF serine-threonine kinases, Mek1/2 (MAP kinase kinases), and ERK1/2 (Extracellular signal Regulated Kinases), responsible for cell differentiation and migration as well as for control of apoptosis. The final point of MAPK pathway involves modification of activity manifested by transcription factors, ELK (ETS domain-containing Elk1). Transcription factors, SRF (Serum Response Factor) and ELK1 participate in control of expression exhibited by genes, the protein products of which cooperate in transmission of mitogenic signals. In this way phosphorylated ERK transmits consecutive signals to cell nucleus, which evokes the mitogenic response: progress in cell cycle and cell proliferation $[10,37,88]$. Similarly to AKT pathway, the final target of ERK action involves the BAD protein, which prevents against apoptosis. The Ras-->Raf-->ERK1/2 pathway may also be activated by phosphorylation of tyrosine in IRS. This results in formation of IRS-GRB2-SOS complex, which activates RAS [27, 87].

A ligand binding to IGF-1R leads also to activation of potential-dependent calcium channels and to transient increase in intracellular level of $\mathrm{Ca} 2+$ ions, exerting an influence on activity of calcium ion-dependent transcription factors, such as MEF2 (Mads box transcription Enhancer Factor-2), NFAT (Nuclear Factors of Activated T-cells) and CREB (cAMP Response Element-Binding), which amplify expression of numerous antiapoptotic proteins, including BCL2. The elevated levels of $\mathrm{Ca} 2+$ ions in cytoplasm activate the protein phosphatase, calcineurin, disturbing 
action of calmodulin. Activation of calcineurin leads to dephosphorylation of NFAT and to its transport to the cell nucleus, in which, together with other factors it binds with soecific regulatory elements in genes of defined protooncogenes [56, 87].

Analysis of gene expression in human fibroblasts in response to IGF-1 demonstrated expression of, i.a., such proteins as POST (Periostin Osteoblast Specific Factor, POST), engaged in metastasis and angiogenesis [76]; TNC (Tenascin-C), which stimulates cell proliferation and LOXL1 (Lysyl Oxidase-Like 1), the protein belonging to family of oxidases, engaged in the process of neoplastic invasion.[51, 87]

Transmission of signals along the IGF-I-IGF-1R pathway carries importance in both physiological and pathological conditions [3, 16, 23, 25, 87]. In normal cells IGF-I stimulates DNA synthesis and is required for cell passage to the phase $\mathrm{S}$ of the cell cycle. IGF-I plays also an important role in development of a hypertrophic response, leading to an increased expression of contractile proteins, such as actin, myosin or troponin [13]. Taking advantage of tyrosine kinase, PI3K and MAPK, IGF-1R pathways may help in decreasing the risk of cardiac disease by preventing against apoptosis [48]. In cells not stimulated by IGF tyrosine kinase activity remains inhibited due to interactions between amino acid residues in the loop responsible for its activation and other residues in the kinase domain as well as between kinase domain and and the receptor-neighbouring region in the cell membrane [51].

The presented transmission of signal along the IGF-1/IGF -1R axes is very complex and it develops with involvement of numerous molecules forming a specific network within the cell, in which most of the components play role of mediators in actions of numerous hormones, growth factors or cytokine receptors. The pattern of molecule interactions within the network, their kinetics and intracellular localization exert effect on alterations in cell behaviour, control of their growth and division $[4,51,88]$. Due to its endo-, para- and autocrine action, IGF system plays the incompletely clarified yet function in development of many tumours. The obtained till now scientific clinical data $[3,23,25,27,31,54,57,62,64$, $66,79]$ accentuate the need for better understanding of IGF signaling, which would allow physicians to identify patient's neoplastic phenotype and to reach the highest probability of obtaining advantages from such an directional approach, particularly important in the antineoplastic therapy.

\section{REFERENCES}

[1] Alami N, Page V, Yu Q, Jerome L, Paterson J, Shiry L, Leyland-Jones B. Recombinant human insulin -like growth factor- binding protein 3 inhibits tumor growth and targets the Akt pathway in lung and colon cancer models. Growth Horm IGF Res 2008; 18: 487-496.

[2] AккірRiк M, Hu L, SAhin A, Hao X, Zhang W. The subcellular localization of IGFBP5 affects its cell growth and migration functions in breast cancer. BMC Cancer 2009; 9: 103. doi:10.1186/1471-2407-9-103 
[3] Attias-Geva ZA, Bentov I, Ludwig DL, Fishman A, Bruchim I, Werne H. Insulin-like growth factor -I receptor (IGF-IR) targeting with monoclonal antibody cixutumumab (IMCA12) inhibits IGF-I action in endometrial cancer cells. Eur. J Cancer 2011; 47: 1717-1726.

[4] Atzori F, Tabernero J, Cervantes A, Prudkin L, Andreu J, Rodríguez-Braun E, Domingo A, Guijarro J, Gamez C, Rodon J, Di Cosimo S, Brown H, Clark J, Hardwick JS, Beckman RA, Hanley WD, Hsu K, Calvo E., Roselló S, Langdon RB, Baselga J. A phase I pharmacokinetic and pharmacodynamic study of dalotuzumab (MK-0646), an anti-insulin-like growth factor-1 receptor monoclonal antibody, in patients with advanced solid tumors. Clin Cancer Res 2011; 17: 6304-6312.

[5] Avruch J. MAP kinase pathawy: the first twenty years. Bioch Physiol Acta 2010; 1773: 1150-1160.

[6] Baraniak AP, Chen JR, Garcia-Blanco A. Fox-2 mediates epithelial cell-specific fibroblast growth factor receptor 2 exon choice. Mol Cell Biol. 2006; 26: 1209-1222.

[7] BARTON ER. The ABC of IGF-I isoforms: impact on muscle hyprtrophy and implication for repair. App. Physiol. Nutr. Metab. 2006; 31: 791-797.

[8] Barton ER, DeMeo J, Lei H. The insulin-like growth factor (IGF-I) E-peptydes are required for isoform specific gene expression and muscle hypertrophy after local IGF-I production. J Appl Physiol. 2010; 108: 1069-1076.

[9] BASERGa R. Customizing the targeting of IGF-1 receptor. Future Oncol 2009; 5: 43-50.

[10] Becker MA, Ibrahim YH, Cui X, Lee AU, Yee D. The IGF pathway regulates ER alpha through a S6K1dependent mechanism in breast cancer cells. Mol.Endocrinol 2011; 3: 516-528.

[11] Belizon A, Balik E, Kirman I, Remotti H, Ciau N, Jain S, Whelan RL. Insulin-like growth factor binding protein-3 inhibits colitis-induced carcinogenesis. Dis Colon Rectum 2007; 50: 1377-83.

[12] Benyoucef S, Surinya KH, HadaschiK D, Siddle K. Characterization of insulin/IGF hybrid receptors: contributions of the insulin receptor L2 and Fn1 domains and the alternatively spliced exon 11 sequence to ligand binding and receptor activation. Biochem J 2007; 40: 603-13.

[13] Bouskila M, Hunter RW, Ibrahim AF, Delattre L, Peggie M, van Diepen Ja, Voshol PJ, Jensen J, SАКАмото K. Allosteric regulation of glycogen synthesis controls glycogen in muscle. Cell Metabolism 2010; 12: 456-466.

[14] Bracko O, Singer T, Aigner S, Knobloch M, Winner B, Ray J, Clemenson GD Jr, Suh H, Couillard -Despres S, Aigner L, Gage FH, Jessberger S. Gene expression profiling of neural stem cells and their neuronal progeny reveals IGF2 as a regulator of adult hippocampal neurogenesis. J Neurosci. 2012 7; 32: 3376-3387.

[15] Brown J, Jones EY, Forbes BE. Keeping IGF-II under control: lessons from the IGF-II-IGF2R crystal structure. Trends Biochem Sci 2009; 34: 612-619.

[16] Butt AJ, Dickson KA, McDougall F, Baxter RC. Insulin-like growth factor-binding protein-5 inhibits the growth of human breast cancer cells in vitro and in vivo. J Biol Chem 2003; 278(32): 29676-2985.

[17] Carapancea M, Cosaceanu D, Budiu R, Kwiecinska A, Tataranu L, Ciubotaru V, Alexandru O, Banita M, Pisoschi C, Bäcklund ML, Lewensohn R, Dricu A. Dual targeting of IGF-1R and PDGFR inhibits proliferation in high-grade gliomas cells and induces radiosensitivity in JNK-1 expressing cells. J Neurooncol 2007; 85: 245-254.

[18] Clemmons DR. Physiology of insulin-like growth factor I. www.uptodate.com /contens/physiology of insulin growth factor $/ 2012$. JOURNAL

[19] Clemmons DR. Clinical utility of measurements of insulin-like growth factor 1. Nat Clin Pract Endocrinol Metab 2006; 2: 436-446.

[20] Clemmons DR. Involvement of insulin-like growth factor-I in the control of glucose homeostasis. Curr Opin Pharmacol 2006; 6: 620-630.

[21] Datta SR, Dudek H, Tao X, Masters S, Fu H, Gotoh Y, Greenberg ME. Akt phosphorylation of BAD couples survival signals to the cell-intrinsic death machinery. Cell 1997; 91: 231-241.

[22] DeMambro VE, Clemmons DR, Horton LG, Bouxsein ML, Wood Tl, Beamer WG, Canalis E, RoSEN CJ. Gender-specific changes in bone turnover and skeletal architecture in IGFBP-2-null mice. Endocrinology 2008; 149: 2051-2061. 
[23] Di Cosimo S, Bendell JC, Cervantes-Ruiperez A. A phase I study of the oral mTOR inhibitor ridaforolimus (RIDA) in combination with the IGF-1R antibody dalotozumab (DALO) in patients (pts) with advanced solid tumors. J Clin Oncol 2010; 28(Suppl 15): 3008.

[24] Durai R, Yang SY, Sales KM, Seifalian AM, Goldspink G, Winslet MC: Insulin-like growth factor binding protein- 4 gene therapy increases apoptosis by altering Bcl-2 and Bax proteins and decreases angiogenesis in colorectal cancer. Int J Oncol 2007; 30: 883-888.

[25] Durai R, Yang SY, Seifalian AM, Goldspink G, Winslet MC. Role of insulin-like growth factor binding protein-4 in prevention of colon cancer. World J Surg Oncol 2007; 5: 128-136.

[26] Durai R, Yang SY, Sales KM, Seifalian AM, Goldspink G,Winslet MC. Increased apoptosis and decreased proliferation of colorectal cancer cells using insulin-like growth factor binding protein-4 gene delivered locally by gene transfer. Colorectal Dis 2007; 9: 625-635.

[27] Dziadziuszko R, Merrick DT, Witta SE. Insulin-like growth factor receptor 1(IGF1R) gene copy number is associated with survival in operable non-smallcell lung cancer: a comparison between IGF1R fluorescent in situ hybridization, protein expression, and mRNA expression. J Clin Oncol 2010; 28: 2174-2180.

[28] Ester WA, Hokken-Koelega AC. Polymorphisms in the IGF1 and IGF1R genes and children born small for gestational age: results of large population studies. Best Pract Res Clin Endocrinol Metab 2008; 22: 415-431.

[29] Frasca F, Pandini G, Sciacca L, Pezzino V, Squatrito S, Belfiore A, Vigneri R: The role of insulin receptors and IGF-I receptors in cancer and other diseases. Arch Physiol Biochem 2008; 114: 23-37.

[30] Gariboldi MB, Ravizza R, Monti E. The IGFR1 inhibitor NVP-AEW541 disrupts a pro-survival and pro-angiogenic IGF-STAT3-HIF1 pathway in human glioblastoma cells. Biochem Pharmacol 2010; 80: $455-462$.

[31] Haluska P, Carboni JM, TenEyck C, Attar RM, Hou X, Yu C, Sagar M, Wong TW, Gottardis MM, ERLICHMAN C. HER receptor signaling confers resistance to the insulin-like growth factor-I receptor inhibitor, BMS-536924. Mol Cancer Ther 2008; 7: 2589-2598.

[32] Haluska P, Shaw HM, Batzel GN, Yin D, Molina JR, Molife LR, Yap TA, Roberts ML, Sharma A, Gualberto A, Adjei AA, De Bono JS. Phase I dose escalation study of the anti insulin-like growth factor-i receptor monoclonal antibody CP-751,871 in patients with refractory solid tumors. Clin Cancer Res 2007; 13: 5834-5840.

[33] Heidegger I, Pircher A, Klocker H, Massoner P. Targeting the insulin-like growth factor network in cancer therapy. Cancer Biol Therapy 2011; 11: 701-707.

[34] Hwa V, Он Y, Rosenfeld RG. The insulin-like growth factor binding protein (IGFBP) superfamily Endocrine Reviev 1999; 20: 761-787.

[35] Huang J, Manning BD. A complex interplay between Akt, TSC2 and the two mTOR complexes. Biochem Soc Trans 2009; 37: 217-22.

[36] Jenab M, Riboli E, Cleveland RJ, Norat T, Rinaldi S, Nieters A, Biessy C, Tuønneland A, Olsen A, Overvad K, Grønbaek H, Clavel-Chapelon F, Boutron-Ruault MC, Linseisen J, Boeing H, Pischon T, Trichopoulos D, Oikonomou E, Trichopoulou A, Panico S, Vineis P, Berrino F, Tumino R, Masala G, Peters PH, van Gils CH, Bueno-de-Mesquita HB, Ocké MC, Lund E, Mendez MA, Tormo Mu, Barricarte A, Martínez-García C, Dorronsoro M, Quirós JR, Hallmans G, Palmqvist R, Berglund G, Manjer J, Key T, Allen NE, Bingham S, Khaw KT, Cust A, Kaaks R. Serum C-peptide, IGFBP-1 and IGFBP-2 and risk of colon and rectal cancers in the European Prospective Investigation into Cancer and Nutrition. Int J Cancer 2007; 121: 368-376.

[37] Ji QS, Mulvihill MJ, Rosenfeld-Franklin M. A novel, potent, and selective insulin-like growth factor-i receptor kinase inhibitor blocks insulin-like growth factor-i receptor signaling in vitro and inhibits insulin-like growth factor-i receptor dependent tumor growth in vivo. Mol Cancer Ther 2007; 6: 2158-2167.

[38] Jozefiak A, Pacholska-Bogalska J, Myga-Nowak M, Kedzia W, Kwasniewska A, Luczak M, Kedzia H, GozdzicKa-Jozefiak A. Serum and tissue levels of insulin-like growth factor-I in women with dysy plasia and HPV-positive cervical cancer. Mol Med Report. 2008; 1: 231-237. 
[39] Juul A. Serum levels of insulin-like growth factor I and its binding proteins in health and disease. Growth Horm IGF Res 2003; 13: 113-170.

[40] Kang HJ, Yi YW, Kim HJ, Hong YB, Seong YS, Bael J. BRCA1 negatively regulated IGF 1 expression thgrough an estrogen-responsive element-like site, Cell Death.Dis. 2012; 28: 3-15. doi:10.1038/ cddis.2012.78.

[41] Key TJ, Appleby PN, Reeves GK. Insulin-like growth factor 1 (IGF1), IGF binding protein 3 (IGFBP3), and breast cancer risk: pooled individual data analysis of 17 prospective studies. Lancet Oncol 2010; 11: $530-542$.

[42] Knowlden JM, Jones HE, Barrow D. Insulin receptor substrate-1 involvement in epidermal growth factor receptor and insulin-like growth factor receptor signalling: implication for gefitinib ('Iressa') response and resistance. Breast Cancer Res Treat 2008; 111: 79-91.

[43] Kotronen A, Lewitt M, Hall K, Brismar K, Yki-Järvinen H. Insulin-like growth factor binding protein 1 as a novel specific marker of hepatic insulin sensitivity. J Clin Endocrinol Metab 2008; 93: 4867-4872.

[44] Laursen LS, KJaer-Sorensen K, Andersen MH. Regulation of insulin-like growth factor (IGF) bioactivity by sequential proteolytic cleavage of IGF binding protein-4 and -5. Mol Endocrinol 2007; 21:1246-1257.

[45] Liu BA, Jablonowski K, Shah EF, Engelmann BW, Jones RB, Nash PD. SH2 domains recognize contexual peptide sequence information to determine selectivity. Mol Cell Proteomics 2010;9: 23912404. doi:10.1074/mcp/M110.001586.

[46] Liu B, Lee KW, Anzo M, Zhang B, Zi X, Tao Y, Shiry L, Pollak M, Lin S, Cohen P. Insulin-like growth factor-binding protein-3 inhibition of prostate cancer growth involves suppression of angiogenesis. Oncogene 2007; 26: 1811-1819.

[47] Ma J, Sawai H, Matsuo Y, Ochi N, Yasuda A, Takahashi H, Wakasugi T, Funahashi H, Sato M, TakeyAMA H. IGF-1 mediates PTEN suppression and enhances cell invasion and proliferation via activation of the IGF-1/PI3K/Akt signaling pathway in pancreatic cancer cells. J Surg Res 2010; 160: 90-101.

[48] Mairet-Coello G, Tury A, DiCicco-Bloom E. Insulin-like growth factor-1 promotes G(1)/S cell cycle progression through bidirectional regulation of cyclins and cyclin-dependent kinase inhibitors via the phosphatidylinositol 3-kinase/Akt pathway in developing rat cerebral cortex. J Neurosci 2009; 29: 775-788.

[49] Maloney EK, Mclaughlin J, Dagdigian NE, Garrett LM, Connors KM, Zhou XM, Blatter Wa, Chittenden T, Singh R. An anti-insulin-like growth factor I receptor antibody that is a potent inhibitor of cancer cell proloferation. Cancer Res 2003; 63: 5073-5083.

[50] Massoner P, Colleselli D, Matscheski A, Pircher H, Geley S, Jansen Dürr P, Klocker H. Novel mechanism of IGF- binding protein-3 action on prostate cancer cells: inhibition of proliferation, adhesion and motility. Endocr Relat Cancer 2009; 16: 795-808.

[51] Matheny RW JR, Nindl BC, Adamo LA. A putative product of IGF-I gene expression involved in tissue repair and regeneration. Endocrinology 2010; 151: 865-875.

[52] Mita K, Zhang Z, Ando Y, Toyama T, Hamaguchi M, Kobayashi S, Hayashi S, Fuji Y, Iwase H, YamaSHITA H. Prognostic significance of insulin-like growth factor binding protein (IGFBP)-4 and IGFBP-5 expression in breast cancer. Jpn J Clin Oncol 2007; 37: 575-582.

[53] Musaro A., Dobrowolny G., Rosenthal N. The neuroprotective effects of a locally acting IGF-I isoform. Ex Gerontol. 2007; 42: 76-80.

[54] Olmos D, Postel-Vinay S, Molife LR, Okuno SH, Schuetze SM, Paccagnella Ml, Batzel GN, Yin D, Pritchard-Jones K, Judson I, Worden FP, Gualberto A, Scurr M, de Bono JS, Haluska P. Safet y, pharmacokinetics, and preliminary activity of the anti-IGF-1R antibody figitumumab (CP-751,871) in patients with sarcoma and Ewing's sarcoma: a phase 1 expansion cohort study. Lancet Oncol 2010; 11: 129-135.

[55] Pacholska-Bogalska J, Józefiak A, Nowak W, Kedzia W, Kwaśniewska A, Goździcka-Józefiak A. Association of the IGF-I promoter P1 polymorphism with risk of cervical cancer. Eur J Gynaecol Oncol. 2011; 32: 393-408. 
[56] Pandini G, Wurch T, Akla B, Corvaia N, Belfiore A, Goetsch L. Functional responses and in vivo anti-tumour activity of h7C10: a humanised monoclonal antibody with neutralising activity against the insulin-like growth factor-1 (IGF-1) receptor and insulin/IGF-1 hybrid receptors. Eur J Cancer 2007; 43: 1318-1327.

[57] Pappo AS, Patel SR, Crowley J, Reinke DK, Kuenkele KP, Chawla SP, Toner GC, Maki RG, Meyers Pa, Chugh R, Ganjoo KN, Schuetze SM, Juergens H, Leahy MG, Geoerger B, Benjamin RS, HeLmAN LJ, BAKER LH. R1507, a monoclonal antibody to the insulin-like growth factor 1 receptor, in patients with recurrent or refractory Ewing sarcoma family of tumors: results of a phase II Sarcoma Alliance for Research through Collaboration study. J Clin Oncol. 2011; 29: 4541-4547.

[58] Pearce Cl, Doherty Ja, Van den Berg DJ, Moysich K, Cushing-Haugen KL, Conti DV, Ramus SJ, Gentry-Maharaj KL, Menon U, Gayther Sa, Pharoah PD, Song H, Kuaer SK, Hogdall E, Hogdall C, Whitemorre AS, Mc Guire V, Sieh W, Grunwald J, Madrek K, Jakubowska A, Lublinski J, Trench GC, AOCS/ASC Study Group, Beesley J, Webb PM, Berschuk A, Schildkraut JM, Iversen ES, Moorman PG, Edlund CK, Stram DO, Pike MC, Ness RB, Wu AH: Genetic variation in insulin -like growth factor-2 may play a role in ovarian cancer risk. Hum Mol Genetics 2011; 20: 2263-2272.

[59] Philippou A, Halapas A, Maridaki M, Koutsilieris M. Type I insulin-like growth factor receptor signaling in skeletal muscle regeneration and hypertrophy. J Musculoskelet Neuronal Interact 2007; 7: 208-215.

[60] Pollak M. Insulin and insulin-like growth factor signaling in neoplasia. Nat Rev Cancer 2008; 12: 915-928.

[61] Price AJ, Allen Ne, Appleby PN, Crowe Fl, Travis RC, Tipper SJ, Overvad K, Grønbek H, Tuønneland A, Johnsen NF, Rinaldi S, Kaaks R, Lukanova A, Boeing H, Aleksandrova K, Trichopoulou A, Trichopoulos D, Andarakis G, Palli D, Krogh V, Tumino R, Sacerdote C, Bueno-de-Mesquita hB, Argüelles MV, Sánchez MJ, Chirlaque MD, Barricarte A, Larrañaga N, González CA, Stattin P, Johansson M, Khaw KT, Wareham N, Gunter M, Riboli E, Key T. Insulin-like Growth Factor-I Concentration and Risk of Prostate Cancer: Results from the European Prospective Investigation into Cancer and Nutrition. Cancer Epidemiol Biomarkers Prev 2012; 2: 1531-1541.

[62] Rajpathak SN, Gunter MJ, Wylie-Rosett J, Ho GY, Kaplan RC, Muzumdar R, Rohan TE, Strickler HD. The role of insulin-like growth factor-I and its binding proteins in glucose homeostasis and type 2 diabetes. Diabetes Metab Res Rev 2009; 25: 3-12.

[63] Rajski M, Zanetti-Dallenbach R, Vogel B, Herrmann R, Rochlits Ch, Buess M. IGF 1 induced genes in stromal fibroblasts predict the clinical outcome of breast and lung cancer patients. BMC Medicine 2010; 8: www.biomedcentral.com/1741-7051/8/1

[64] Reidy DL, Vakiani E, Fakih MG, Saif MW, Hecht JR, Goodman-Davis N, Hollywood E, Shia J, Schwartz J, Chandrawansa K, Dontabhaktuni A, Youssoufian H, Solit DB, Saltz LB. Randomized, phase II study of the insulin-like growth factor-1 receptor inhibitor IMC-A12, with or without cetuximab, in patients with cetuximab- or panitumumab-refractory metastatic colorectal cancer. J Clin Oncol 2010; 28: 4240-4246.

[65] Rinaldi S, Cleveland R, Norat T, Biessy C, Rohrmann S, Linseisen J, Boeing H, Pischon T, Panico S, Agnoli C, Palli D, Tumino R, Vineis P, Peeters PH, van Gils CH, Bueno-de-Mesquita BH, Vrieling A, Allen Ne, Roddam A, Bingham S, Khaw KT, Manjer J, Borgquist S, Dumeaux V, Torhild Gram I, Lund E, Trichopoulou A, Makrygiannis G, Benetou V, Molina E, Donate Suárez I, Barricarte Gurrea A, Gonzalez CA, Tormo MJ, Altzibar JM, Olsen A, Tuonneland A, Grønbaek H, Overvad K, Clavel-Chapelon F, Boutron-Ruault MC: Serum levels of IGF-I, IGFBP-3 and colorectal cancer risk: results from the EPIC cohort, plus a meta-analysis of prospective studies. Int J Cancer 2010; 126: $1702-1715$.

[66] Rho SB, Dong SM, Kang S, Seo SS, Yoo CW, Lee DO, Woo JS, Park SY. Insul in-1 ike gr owth factors, their binding proteins, and prostate cancer risk: analysis of individual patient data from 12 prospective studies. Ann Intern Med 2008; 149: 461-471. 
[67] Rodon J, DeSantos V, Ferry RJ Jr, Kurzrock R. Early drug development of inhibitors of the insulin -like growth factor-ireceptor pathway: lessons from the first clinical trials. Mol Cancer Ther 2008; 7: 2575-2588.

[68] Sakauchi F, Nojima M, Mori M. Serum insulin-like growth factors I and II, insulin-like growth factor binding protein-3 and risk of breast cancer in the Japan Collaborative Cohort study. Asian Pac J Cancer Prev 2009; 10: 51-55.

[69] Samani AA, YaKar S, LeRoith D, Brodt P. The role of the IGF system in cancer growth and metastasis: overview and recent insights. Endocrinol Rev 2007; 28: 20-47.

[70] Santosh V, Arivazhagan A, Sreekanthreddy P, Srinivasan H, Thota B, Srividya MR, Vrinda M, Sridevi S, Shailaja BC, Samuel C, Prasanna KV, Thennarasu K, Balasubramaniam A, Chandramouli BA, Hegde AS, Somasundaram K, Kondaiah P, Rao MR. Grade-specific expression of insulin-like growth factor-binding proteins-2, -3 , and -5 in astrocytomas: IGFBP-3 emerges as a strong predictor of survival in patients with newly diagnosed glioblastoma. Cancer Epidemiol Biomarkers Prev 2010; 19: $1399-1408$.

[71] Scicchitano BM, Rizzuto E, Musaro A. Counteracting muscle casting in aging and neuromuscular dis eses: the critical role of IGF-I. Aging (Albany NY) 2009; 1: 451-457.

[72] Schlenska-Lange A, Knüpfer H, Lange TJ, Kiess W, Knüpfer M. Cell proliferation and migration in glioblastoma multiforme cell lines are influenced by insulin-like growth factor I in vitro. Anticancer Res 2008; 28: 1055-1060.

[73] Schütt BS, Langkamp M, Rauschnabel U, Ranke MB, Elmlinger MW. Integrin-mediated action of insulin-like growth factor binding protein-2 in tumor cells. J Mol Endocrinol 2004; 32: 859-868.

[74] SidDLE K. Signaling by insulin and IGF receptors: supporting acts and new players. J Mol Endocrinol 2011; 47: R1-R10. DOI:10.1530/JME/11-0022.www.endockrinology-journals.org??

[75] Shao R, Bao S, Bai X, Blanchette C, Anderson RM, Dang T., Goshizky ML, Marks JR, Wang XF. Acquired expression of periostin by human breast cancer promoters tumor angiogenesis through up -regulation of vascular endothelial growth receptor 2 expression, Mol Cell Biol 2004; 24: 3992-4003.

[76] Song R. X-D,Chen Y, Zhang Z, Bao Y, Yue W , WAng J-P. Estrogen utilization of IGF-I-R and EGF-R to signal in breast cancer cells. J Steroid Bioch Mol Biology 2010; 118: 219-230.

[77] Stratikopoulos E, Szabolcs M, Dragatsis I, Klinakis A, Efstratiadis A. The hormonal action of IGF1 in postnatal mouse growth. Proc Natl Acad Sci U S A 2008; 105: 19378-19383.

[78] Suzuki S, Kojima M, Tokudome S et al. Insulin-like growth factor (IGF)-I, IGF-II, IGF binding proe tein-3, and risk of colorectal cancer: a nested case-control study in the Japan Collaborative Cohort study. Asian Pac J Cancer Prev 2009; 10: 45-49.

[79] Tap WD, Demetri G, Barnette P, Desai J, Kavan P, Tozer R, Benedetto PW, Friberg G, Deng H, McCaffery I, Leitch I, Badola S, Chang S, Zhu M, Tolcher A. Phase II study of ganitumab, a fully human anti-type-1 insulin-like growth factor receptor antibody, in patients with metastatic Ewing family tumors or desmoplastic small round cell tumors. J Clin Oncol. 2012 May 20; 30: 1849-1856.

[80] Tarn C, Rink L, Merkel E, Flieder D, Pathak H, Koumbi D, Testa JR, Eisenberg B, von Mehren M, GoDwIN AK. IGF-independent effects of insulin-like growth factor binding protein-5 (Igfbp5) in vivo. FASEB J 2009; 23: 2616-2626.

[81] Wallis M. New insul in- 1 ike growth factor (IGF) -precur sor sequences from mammal ian genomes: the molecular evolution of IGFs and associated peptides in primates. Growth Hor IGF Res 2009; 19: $12-23$

[82] Wang H, Arun BK, Wang H, Fuller GN, Zhang W, Middleton LP, SAhin AA. IGFBP2 and IGFBP5 overexpression correlates with the lymph node metastasis in T1 breast carcinomas. Breast J 2008;14: 261-267.

[83] Wang GK, Hu L, Fuller GN, Zhang W. An interaction between insulin-like growth factor-binding protein 2 (IGFBP2) and integrin alpha5 is essential for IGFBP2- induced cell mobility. J Biol Chem 2006; 281: 14085-14091. 
[84] Werner H, Weinstein D, Bentov I. Similarities and differences between insulin and IGF-I: structures, receptors, and signalling pathways. Arch Physiol Biochem 2008; 114: 17-22.

[85] Werner H, Bruchim I. The insulin-like growth factor-I receptor as an oncogene. Arch Physiol Biochem 2009; 115: 58-71.

[86] Weroha S, Haluska P. IGF-1 receptor inhibitors in clinical trials - early lessons. J Mamm Gland Biol Neoplasia 2008; 13: 471-483.

[87] Weroha SJ, Haluska P. The insulin-like growth factor system in cancer. Endocrinol Metab Clin North Am. 2012; 41: 335-350.

[88] Yamada PM, Lee KW. Perspectives in mammalian IGFBP-3 biology: local vs. systemic action. Am J Physiol Cell Physiol 2009; 296: 954-976.

[89] YAng SY, Goldspink G. Different role of the IGF-1 Ec peptide (MGF) and mature IGF-1 in myoblast proliferation and differentiation, FEBS Letters 2002; 522: 156-160

[90] Yang SY, Sales KM, Fuller B, Seifalian AM, Winslet MC. Apoptosis and colorectal cancer: implications for therapy.Trends Mol Med 2009; 15: 225-233.

[91] YAng SY, Miah A, PABARI A, Winslet M. Growth factors and their receptors in cancer metastases. Front Biosci 2011; 16: 531-538.

[92] Yang Sy, Sales KM, Fuller BJ, Seifalian AM, Winslet MC. Inducing apoptosis of human colon cancer cells by an igf-I D domain analogue peptide. Mol Cancer 2008; 7: 17-27.

[93] Zhu W, Shiojima I, Ito Y, Li Z, Ikeda H, Yoshida M, Naito AT, Nishi J, Ueno H, Umezawa A, Minamino T, Nagai T, KikUchi A, Asashima M, Komuro I. IGFBP-4 is an inhibitor of canonical WNT signaling required for cardiogenesis. Nature 2008; 454: 345-359.

Editor-Bożena Kamińska

\author{
Wojciech Kwaśniewski \\ Chair and Department of Oncological Gynaecology and Gynaecology \\ Medical University of Lublin \\ Staszica 16 Street \\ 20-081 Lublin \\ tel.: 510249289 \\ e-mail:wojciech.kwasniewski@umlub.pl
}

